\title{
Clinical utility of patiromer, sodium zirconium cyclosilicate, and sodium polystyrene sulfonate for the treatment of hyperkalemia: an evidence-based review
}

\author{
This article was published in the following Dove Press journal: \\ Core Evidence \\ 23 March 2017 \\ Number of times this article has been viewed
}

\section{Mario V Beccari* \\ Calvin J Meaney*}

Department of Pharmacy

Practice, School of Pharmacy and

Pharmaceutical Sciences, University at

Buffalo, Buffalo, NY, USA

*These authors contributed equally to this work
Correspondence: Calvin J Meaney

Department of Pharmacy Practice, School of Pharmacy and Pharmaceutical Sciences, University at Buffalo, 312 Kapoor Hall, Buffalo, NY I 42 I4-0833, USA

$\mathrm{Tel}+\mathrm{I} 7166452826$

Fax +l 7168296093

Email cjmeaney@buffalo.edu
Introduction: Hyperkalemia is a serious medical condition that often manifests in patients with chronic kidney disease and heart failure. Renin-angiotensin-aldosterone system inhibitors are known to improve outcomes in these disease states but can also cause drug-induced hyperkalemia. New therapeutic options exist for managing hyperkalemia in these patients which warrant evidence-based evaluation.

Aim: The objective of this article was to review the efficacy and safety evidence for patiromer, sodium zirconium cyclosilicate (ZS9), and sodium polystyrene sulfonate (SPS) for the treatment of hyperkalemia.

Evidence review: Current treatment options to enhance potassium excretion are SPS and loop diuretics, which are complicated by ambiguous efficacy and known toxicities. Patiromer and ZS9 are new agents designed to address this treatment gap. Both unabsorbable compounds bind potassium in the gastrointestinal (GI) tract to facilitate fecal excretion. The capacity to bind other medications in the GI tract infers high drug-drug interaction potential, which has been demonstrated with patiromer but not yet investigated with ZS9 or SPS. Phase II and III clinical trials of patiromer and ZS9 demonstrated clear evidence of a dose-dependent potassiumlowering effect and the ability to initiate, maintain, or titrate renin-angiotensin-aldosterone system inhibitors. There is limited evidence base for SPS: two small clinical trials indicated potassium reduction in chronic hyperkalemia. All agents may cause adverse GI effects, although they are less frequent with ZS9. Concerns remain for SPS to cause rare GI damage. Electrolyte abnormalities occurred with patiromer and SPS, whereas urinary tract infections, edema, and corrected QT-interval prolongations were reported with ZS9.

Conclusion: Patiromer and ZS9 have improved upon the age-old standard SPS for the treatment of hyperkalemia. Additional research should focus on drug-drug interactions in patients on multiple medications, incidence of rare adverse events, and use in high-risk populations.

Keywords: hyperkalemia, patiromer, sodium zirconium cyclosilicate, sodium polystyrene sulfonate, evidence-based review

Core evidence clinical impact summary for patiromer, sodium zirconium cyclosilicate, and sodium polystyrene sulfonate in the treatment of hyperkalemia

\begin{tabular}{|lll|}
\hline Outcome measure & Evidence & Implications \\
\hline $\begin{array}{l}\text { Disease-oriented evidence } \\
\text { Hyperkalemia }\end{array}$ & $\begin{array}{l}\text { Clinical trials and } \\
\text { one observational } \\
\text { study }\end{array}$ & $\begin{array}{l}\text { Patiromer and ZS9 consistently demonstrated } \\
\text { efficacy in the treatment of hyperkalemia. } \\
\end{array}$ \\
& A dose-dependent potassium-lowering effect \\
(Continued)
\end{tabular}

Core Evidence 2017:12 II-24 


\begin{tabular}{|c|c|c|}
\hline $\begin{array}{l}\text { (Continued) } \\
\text { Outcome measure }\end{array}$ & Evidence & Implications \\
\hline \multirow{2}{*}{\multicolumn{3}{|c|}{$\begin{array}{l}\text { occurred with both of these agents. Similar } \\
\text { results were observed in subgroups of } \\
\text { patients with chronic kidney disease and/ } \\
\text { or heart failure. Longer trial durations with } \\
\text { patiromer indicate it may be preferred in } \\
\text { chronic hyperkalemia. On the other hand, } \\
\text { ZS9 appears to be the preferred agent for } \\
\text { the treatment of acute hyperkalemia. The } \\
\text { efficacy of SPS for chronic hyperkalemia } \\
\text { was demonstrated in two small randomized } \\
\text { clinical trials. However, overall efficacy is } \\
\text { unclear, due to the observational nature of } \\
\text { past studies and short follow-up periods. }\end{array}$}} \\
\hline & & \\
\hline $\begin{array}{l}\text { Renin-angiotensin- } \\
\text { aldosterone system-inhibitor } \\
\text { utilization }\end{array}$ & $\begin{array}{l}\text { Clinical trials and } \\
\text { one observational } \\
\text { study }\end{array}$ & $\begin{array}{l}\text { lloperidone was more effective than } \\
\text { placebo and similar to haloperidol, } \\
\text { risperidone, and ziprasidone in several } \\
\text { psychometric scales and in symptoms } \\
\text { assessment. }\end{array}$ \\
\hline Safety & $\begin{array}{l}\text { Clinical trials and } \\
\text { one observational } \\
\text { study }\end{array}$ & $\begin{array}{l}\text { Patiromer and ZS9 were generally well } \\
\text { tolerated. The most common adverse } \\
\text { events were nausea, constipation, and } \\
\text { diarrhea, and were mild in severity. Side } \\
\text { effects of hypokalemia, hypomagnesemia, } \\
\text { and gastrointestinal effects were less } \\
\text { frequent with ZS9 compared to patiromer } \\
\text { and SPS. In addition to these adverse } \\
\text { events, the use of SPS has been associated } \\
\text { with hypocalcemia, hypernatremia, and rare } \\
\text { gastrointestinal effects of mucosal damage } \\
\text { and intestinal necrosis. }\end{array}$ \\
\hline
\end{tabular}

\section{Introduction}

Hyperkalemia is a serious medical condition that can cause muscle weakness, paralysis, and cardiac arrhythmias and is associated with increased mortality. ${ }^{1-3}$ Defined as serum potassium greater than $5 \mathrm{mEq} / \mathrm{L}(5 \mathrm{mmol} / \mathrm{L})$, hyperkalemia is rare in the general population because the renal system tightly regulates potassium homeostasis. ${ }^{4}$ However, renal insufficiency is often associated with hyperkalemia via multiple mechanisms: decreased renal excretion of potassium, which increases total body potassium content, transcellular potassium shift due to metabolic acidosis, and increased dietary intake through salt substitutes. ${ }^{4-6}$ Hyperkalemia is most often encountered in patients with chronic kidney disease (CKD) and/or heart failure in a variety of care settings. Drug-induced hyperkalemia is most commonly associated with renin-angiotensin-aldosterone system inhibitors (RAASIs), which are strongly beneficial in patients with heart failure and CKD. ${ }^{5-9}$ Management of hyperkalemia in these patients can include reduction or discontinuation of these beneficial agents, which may have an undesirable impact on patient outcomes. Therefore, there is a strong impetus for new pharmacologic options to treat hyperkalemia in both the acute and chronic settings, in particular among patients on RAASIs.

For decades, sodium polystyrene sulfonate (SPS) was the only US Food and Drug Administration (FDA)-approved treatment for hyperkalemia. However, the variable time to onset of effect and high sodium content of SPS (Table 1) make it a poor choice in acute hyperkalemia and sodium-restricted patient populations, respectively. ${ }^{10,11}$ SPS lacks robust, randomized, controlled clinical trial efficacy data and has known gastrointestinal (GI) and electrolyte adverse effects. ${ }^{11-16}$ With unknown efficacy and lingering safety concerns, clinicians have struggled to manage hyperkalemia with SPS..$^{15,17}$

Patiromer sorbitex calcium (patiromer) and sodium zirconium cyclosilicate (ZS9) have been developed in an attempt to overcome the gaps and limitations to currently available therapy. ${ }^{18,19}$ The purpose of this review was to present critically the available efficacy and safety evidence for patiromer, ZS9, and SPS in the treatment of hyperkalemia. This encompasses data for use of these agents in special populations, comparison between agents, analysis 
Table I Pharmacologic comparison of potassium-lowering agents

\begin{tabular}{|c|c|c|c|}
\hline $\begin{array}{l}\text { Pharmacologic } \\
\text { property }\end{array}$ & $\begin{array}{l}\text { Sodium polystyrene } \\
\text { sulfonate (SPS) }{ }^{\prime \prime}\end{array}$ & $\begin{array}{l}\text { Patiromer calcium } \\
\text { sorbitex }^{20-22}\end{array}$ & Sodium zirconium cyclosilicate ${ }^{18,23-25}$ \\
\hline Brand name & Kayexalate & Veltassa & None (not FDA-approved) \\
\hline Mechanism of action & $\begin{array}{l}\text { Binds potassium in the } \\
\text { gastrointestinal tract and } \\
\text { facilitates excretion in the feces }\end{array}$ & $\begin{array}{l}\text { Binds potassium in the } \\
\text { gastrointestinal tract and } \\
\text { facilitates excretion in the feces }\end{array}$ & $\begin{array}{l}\text { Binds potassium in the gastrointestinal tract and } \\
\text { facilitates excretion in the feces }\end{array}$ \\
\hline $\begin{array}{l}\text { Selectivity for } \\
\text { potassium ion }\end{array}$ & $\begin{array}{l}\text { Nonselective; also binds } \\
\text { calcium and magnesium }\end{array}$ & Selective; also binds magnesium & $\begin{array}{l}\text { Highly selective; nine times the potassium-binding } \\
\text { capacity compared to SPS; also binds ammonium }\end{array}$ \\
\hline Sodium content & $\mathrm{I}, 500 \mathrm{mg}$ sodium per $15 \mathrm{~g}$ dose & No sodium content & Approximately $1,000 \mathrm{mg}$ sodium per $10 \mathrm{~g}$ dose \\
\hline Sorbitol content & $20 \mathrm{~g}$ sorbitol per $15 \mathrm{~g}$ dose & $4 \mathrm{~g}$ sorbitol per $8.4 \mathrm{~g}$ dose & No sorbitol content \\
\hline Onset of effect & Variable; $2-6$ hours & $7-48$ hours & I-6 hours \\
\hline Duration of effect & Variable; 6-24 hours & 12-24 hours & Unclear; appears to be 4-12 hours based on trial data \\
\hline Dosing & $\begin{array}{l}15 \mathrm{~g} P O \text { one to four times } \\
\text { per day }\end{array}$ & $\begin{array}{l}8.4 \mathrm{~g} P O \text { once daily with a meal; } \\
\text { titrated to } 25.2 \mathrm{~g} / \text { day based on } \\
\text { response }\end{array}$ & $\begin{array}{l}\text { I0 g PO three times daily with meals for acute } \\
\text { treatment; } 5,10 \text {, or } 15 \mathrm{~g} \text { PO once daily with breakfast } \\
\text { for chronic treatment (not approved; based on } \\
\text { trial data) }\end{array}$ \\
\hline $\begin{array}{l}\text { Preparation(s)/ } \\
\text { administration }\end{array}$ & $\begin{array}{l}\text { Liquid or powder for } \\
\text { suspension; mix with water } \\
(3-4 \mathrm{~mL} \text { per } \mathrm{g} \text { of drug) and } \\
\text { administer within } 24 \text { hours }\end{array}$ & $\begin{array}{l}\text { Powder for suspension; mix with } \\
\text { water }(90 \mathrm{~mL}) \text { and administer } \\
\text { immediately; store in refrigerator } \\
\left(36-46^{\circ} \mathrm{F} \text { or } 2-8^{\circ} \mathrm{C}\right) \text {; use } \\
\text { within } 3 \text { months upon removal } \\
\text { from refrigerator }\end{array}$ & $\begin{array}{l}\text { White, tasteless powder for suspension; mix vigorously } \\
\text { with water }(240 \mathrm{~mL}) \text { and administer immediately }\end{array}$ \\
\hline
\end{tabular}

Abbreviations: FDA, US Food and Drug Administration; PO, per os (by mouth); SPS, sodium polystyrene sulfonate.

of adverse effects, and application to different practice settings. To accomplish this, the PubMed, Embase, and Web of Science databases were queried for literature that included the terms "patiromer" or "sodium zirconium cyclosilicate" or "ZS9" or "ZS-9" or "sodium polystyrene sulfonate" or "Kayexalate" or "SPS" or "cation exchange resin" AND "randomized clinical trial" from inception to November 7, 2016. Additional literature was found through review of citation lists of pertinent articles.

\section{Pharmacology}

An overview of pharmacologic properties and administration considerations for patiromer, ZS9, and SPS is presented in Table 1. ${ }^{11,18,20-25}$ Patiromer is an organic, unabsorbable potassium-binding polymer. It is formulated with calcium as the exchange ion and sorbitol to improve stability, rather than promote movement through the GI tract, as is the case with SPS. ${ }^{20,21}$ An $8.4 \mathrm{~g}$ dose of patiromer contains approximately $4 \mathrm{~g}$ of sorbitol compared to $20 \mathrm{~g}$ of sorbitol in a $15 \mathrm{~g}$ dose of SPS. ${ }^{21}$ Fecal excretion of potassium bound to patiromer facilitates a reduction in serum potassium concentration in a dose-dependent manner. Recommended dosing is $8.4 \mathrm{~g}$ once daily, titrated to $25.2 \mathrm{~g} /$ day based on response. Clinical trials have utilized a twice-daily dosing regimen (Table 2), but a Phase I trial showed that fecal potassium excretion was similar between $8.4 \mathrm{~g}$ three times daily, $12.6 \mathrm{~g}$ twice daily, and 25.2 g daily. ${ }^{22}$
ZS9 is an inorganic, unabsorbable polymer of zirconium silicate. ${ }^{23}$ It is believed that the ion channels formed by the atomic structure of ZS9 mimic those of endogenous potassium channels. When the sodium (or hydrogen) ion dissociates from ZS9, a negative charge and pore size of $3 \AA$ make potassium $(2.98 \AA)$ the ideal cation for trapping. ${ }^{24}$ This ion trap has $>25$ times the selectivity for potassium over calcium or magnesium, offering an advantage over SPS that is relatively unselective between these three cations. ${ }^{23}$ In vitro, SPS binds $3.1 \mathrm{mEq}$ of potassium per gram of drug, although this appears to decline when examined in vivo to a $1 \mathrm{mEq} / \mathrm{g}$ ratio. ${ }^{11}$ ZS9 possesses nine times the potassium-binding capacity of SPS in vitro. ${ }^{23}$ Extrapolated dosing of ZS9 from clinical trials is three times daily with meals for acute hyperkalemia and once daily with breakfast for chronic hyperkalemia. ${ }^{18}$

Given the pharmacology of these medications, concerns related to binding to other medications in the GI tract, thereby reducing their absorption, have prompted several actions. Patiromer product labeling contains instructions to separate administration of other medications by at least 3 hours. ${ }^{20}$ This is based on in vitro binding studies wherein patiromer significantly bound to 15 of 28 tested medications. ${ }^{26} \mathrm{~A}$ followup in vivo study was completed in healthy volunteers as an open-label, randomized, single-dose, three-period, three-way crossover study (Relypsa [Redwood City, CA, USA], written communication, March, 2016). Twelve of the 15 identified interacting medications from the in vitro study were evaluated 
Table 2 Summary of patiromer clinical studies for the treatment of hyperkalemia

\begin{tabular}{|c|c|c|c|c|}
\hline Study design & Patient population & Primary end point(s) & $\begin{array}{l}\text { Study treatment and } \\
\text { duration }\end{array}$ & Major findings \\
\hline $\begin{array}{l}\text { PEARL-HF: Phase } \\
\text { II, prospective, } \\
\text { randomized, double-blind, } \\
\text { placebo-controlled, } \\
\text { parallel-group clinical trial }{ }^{30}\end{array}$ & $\begin{array}{l}\text { Patients with heart } \\
\text { failure and a potassium } \\
\text { concentration of } \\
4.3-5.1 \mathrm{mEq} / \mathrm{L}(\mathrm{n}=105) \\
\text { with an indication to start } \\
\text { aldosterone-antagonist } \\
\text { therapy }\end{array}$ & $\begin{array}{l}\text { Mean change in potassium } \\
\text { concentration from baseline } \\
\text { to the end of the study } \\
\text { (day 28) }\end{array}$ & $\begin{array}{l}\text { Patiromer } 15 \mathrm{~g} \text { PO twice } \\
\text { daily or placebo for } \\
4 \text { weeks }\end{array}$ & $\begin{array}{l}\text { Baseline potassium } \\
4.69 \mathrm{mEq} / \mathrm{L} \text {; least-squares } \\
\text { mean reduction of } \\
-0.22 \mathrm{mEq} / \mathrm{L} \text { with patiromer; } \\
\text { increase of } 0.23 \mathrm{mEq} / \mathrm{L} \text { with } \\
\text { placebo (mean difference } \\
-0.45 \mathrm{mEq} / \mathrm{L}, P<0.00 \mathrm{I} \text { ) }\end{array}$ \\
\hline $\begin{array}{l}\text { AMETHYST-DN: Phase II, } \\
\text { prospective, randomized, } \\
\text { open-label, dose-ranging } \\
\text { clinical trial }^{29}\end{array}$ & $\begin{array}{l}\text { Outpatients with } \\
\text { hyperkalemia }(>5 \mathrm{mEq} / \mathrm{L}) \text {, } \\
\text { type } 2 \text { diabetes mellitus, } \\
\text { and CKD (eGFR I5-59 } \\
\left.\mathrm{mL} / \mathrm{min} / \mathrm{I} .73 \mathrm{~m}^{2}\right) \text { receiving } \\
\text { an } \mathrm{ACEi}, \mathrm{ARB} \text {, or both } \\
(\mathrm{n}=306)\end{array}$ & $\begin{array}{l}\text { Mean change in potassium } \\
\text { concentration from baseline } \\
\text { to week } 4 \text { or prior to dose } \\
\text { titration }\end{array}$ & $\begin{array}{l}\text { Patiromer } 4.2 \mathrm{~g}, 8.4 \mathrm{~g} \text {, } \\
\text { or } 12.6 \mathrm{~g} \text { PO twice } \\
\text { daily for } 52 \text { weeks } \\
\text { for mild hyperkalemia } \\
(5 . \mathrm{I}-5.5 \mathrm{mEq} / \mathrm{L}) \text {; patiromer } \\
8.4 \mathrm{~g}, 12.6 \mathrm{~g} \text {, or } 16.8 \mathrm{~g} \text { PO } \\
\text { twice daily for } 52 \text { weeks } \\
\text { for moderate hyperkalemia } \\
(5.6-5.9 \mathrm{mEq} / \mathrm{L})\end{array}$ & $\begin{array}{l}\text { Mild hyperkalemia: least- } \\
\text { squares mean reduction of } \\
-0.35 \mathrm{mEq} / \mathrm{L}(95 \% \mathrm{Cl}-0.48 \text { to } \\
-0.22 \mathrm{mEq} / \mathrm{L}) \text { for } 4.2 \mathrm{~g} \text { group, } \\
-0.5 \mathrm{I} \mathrm{mEq} / \mathrm{L}(95 \% \mathrm{Cl}-0.64 \\
\text { to }-0.38 \mathrm{mEq} / \mathrm{L}) \text { for } 8.4 \mathrm{~g} \\
\text { group, and }-0.55 \mathrm{mEq} / \mathrm{L} \text { ( } 95 \% \\
\mathrm{Cl}-0.68 \text { to }-0.42 \mathrm{mEq} / \mathrm{L}) \text { for } \\
\mathrm{I} 2.6 \mathrm{~g} \text { group }(P<0.00 \mathrm{I} \text { for } \\
\text { each group) } \\
\text { Moderate hyperkalemia: } \\
\text { least-squares mean reduction } \\
\text { of }-0.87 \mathrm{mEq} / \mathrm{L}(95 \% \mathrm{Cl}-\mathrm{I} .14 \\
\text { to }-0.60 \mathrm{mEq} / \mathrm{L}) \text { for } 8.4 \mathrm{~g} \\
\text { group, }-0.97 \mathrm{mEq} / \mathrm{L}(95 \% \mathrm{Cl} \\
-1.23 \text { to }-0.7 \mathrm{mEq} / \mathrm{L}) \text { for } \mathrm{I} 2.6 \\
\mathrm{~g} \text { group, and }-0.92 \mathrm{mEq} / \mathrm{L} \\
(95 \% \mathrm{Cl}-\mathrm{I} .17 \text { to }-0.67 \mathrm{mEq} / \mathrm{L}) \\
\text { for } 16.8 \mathrm{~g} \text { group }(P<0.00 \mathrm{I} \text { for } \\
\text { each group) }\end{array}$ \\
\hline \multirow[t]{2}{*}{$\begin{array}{l}\text { OPAL-HK: Phase III } \\
\text { prospective clinical trial } \\
\text { with a single group, single- } \\
\text { blind initial treatment phase } \\
\text { and a randomized, single- } \\
\text { blind, placebo-controlled } \\
\text { withdrawal phase }{ }^{19}\end{array}$} & $\begin{array}{l}\text { Initial 4-week phase: } \\
\text { patients with stage } 3 \text { or } \\
4 \mathrm{CKD}(\mathrm{eGFR} \mathrm{I5-59} \\
\left.\mathrm{mL} / \mathrm{min} / \mathrm{I} .73 \mathrm{~m}^{2}\right) \text { and a } \\
\text { potassium concentration of } \\
5 . \mathrm{I}-6.4 \mathrm{mEq} / \mathrm{L} \text { stabilized on } \\
\text { an RAASI }(\mathrm{n}=243)\end{array}$ & $\begin{array}{l}\text { Initial phase: mean change } \\
\text { in potassium concentration } \\
\text { from baseline to week } 4\end{array}$ & $\begin{array}{l}\text { Initial phase: patiromer } 4.2 \mathrm{~g} \\
\text { PO for mild hyperkalemia } \\
\text { (5. I-5.4 mEq/L) or } \\
8.4 \mathrm{~g} \text { PO for moderate- } \\
\text { to-severe hyperkalemia } \\
(5.5-6.4 \mathrm{mEq} / \mathrm{L}) \text { twice daily } \\
\text { for } 4 \text { weeks }\end{array}$ & $\begin{array}{l}\text { Initial phase: reduction in } \\
\text { potassium concentration } \\
\text { of }-1.01 \pm 0.03 \mathrm{mEq} / \mathrm{L}(95 \% \\
\mathrm{Cl}-1.07 \text { to }-0.95 \mathrm{mEq} / \mathrm{L} \text {, } \\
P<0.00 \mathrm{I})\end{array}$ \\
\hline & $\begin{array}{l}\text { Randomized withdrawal } \\
\text { 8-week phase: patients with } \\
\text { a potassium concentration } \\
\text { of } 3.8-5 \mathrm{mEq} / \mathrm{L} \text { at the end } \\
\text { of the initial phase who had } \\
\text { potassium } \geq 5.5 \mathrm{mEq} / \mathrm{L} \text { at } \\
\text { baseline }(\mathrm{n}=107)\end{array}$ & $\begin{array}{l}\text { Randomized phase: } \\
\text { between-group difference } \\
\text { in the median change in } \\
\text { potassium concentration } \\
\text { over the first } 4 \text { weeks or } \\
\text { to the earliest visit when } \\
\text { potassium was }<3.8 \text { or } \\
\geq 5.5 \mathrm{mEq} / \mathrm{L}\end{array}$ & $\begin{array}{l}\text { Randomized phase: } \\
\text { continued patiromer at } \\
\text { same dose received at week } \\
4 \text { or switched to placebo } \\
\text { for } 8 \text { weeks }\end{array}$ & $\begin{array}{l}\text { Randomized phase: median } \\
\text { change in potassium } \\
\text { concentration was an increase } \\
\text { of } 0.72 \mathrm{mEq} / \mathrm{L} \text { for placebo and } \\
\text { no change (median } 0 \mathrm{mEq} / \mathrm{L}) \\
\text { for patiromer; between-group } \\
\text { difference of }-0.72 \mathrm{mEq} / \mathrm{L} \\
(95 \% \mathrm{Cl}-0.99 \text { to }-0.46 \mathrm{mEq} / \mathrm{L} \text {, } \\
P<0.00 \mathrm{I})\end{array}$ \\
\hline 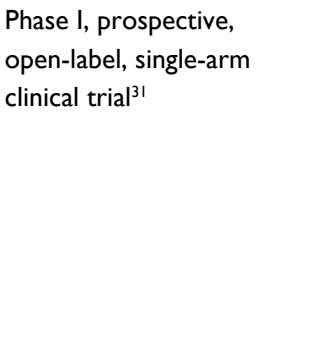 & $\begin{array}{l}\text { Patients with CKD }(\mathrm{eGFR} \\
\left.\mathrm{I}-89 \mathrm{~mL} / \mathrm{min} / \mathrm{I} .73 \mathrm{~m}^{2}\right) \\
\text { and hyperkalemia }(5.5-6.4 \\
\mathrm{mEq} / \mathrm{L}) \text { stabilized on an } \\
\text { RAASI }(\mathrm{n}=25)\end{array}$ & $\begin{array}{l}\text { Change in potassium } \\
\text { concentration from baseline } \\
\text { over } 48 \text { hours; time of } \\
\text { onset when mean change } \\
\text { in potassium concentration } \\
\text { was significant }(P<0.05)\end{array}$ & $\begin{array}{l}\text { Patiromer } 8.4 \mathrm{~g} \text { PO twice } \\
\text { daily with meals for } 2 \text { days }\end{array}$ & $\begin{array}{l}\text { Baseline potassium } 5.93 \\
\mathrm{mEq} / \mathrm{L} \text {; change in potassium } \\
\text { concentration } 7 \text { hours after } \\
\text { the first dose }-0.21 \mathrm{mEq} / \mathrm{L} \\
(95 \% \mathrm{Cl}-0.35 \text { to }-0.07 \mathrm{mEq} / \mathrm{L} \text {, } \\
P=0.004) \text {; mean potassium } \\
\text { concentration decreased to } \\
5.4 \mathrm{I} \mathrm{mEq} / \mathrm{L} \text { by } 20 \text { hours after } \\
\text { the first dose }(P<0.00 \mathrm{I})\end{array}$ \\
\hline
\end{tabular}

Abbreviations: ACEi, angiotensin-converting enzyme inhibitor; ARB, angiotensin-receptor blocker; $\mathrm{Cl}$, confidence interval; CKD, chronic kidney disease; eGFR, estimated glomerular filtration rate; PO, per os (by mouth); RAASI, renin-angiotensin-aldosterone system inhibitor.

in a bioequivalence analysis. When coadministered with patiromer, nine medications did not meet bioequivalence criteria (trimethoprim, clopidogrel, amlodipine, cinacalcet, metoprolol, furosemide, levothyroxine, metformin, and ciprofloxacin), with all medications exhibiting reduced systemic concentrations. However, when administration was 
separated by 3 hours, all medications were bioequivalent, with the exception of ciprofloxacin $(90 \%$ confidence interval [CI] for maximum concentration $83 \%-133.8 \%$, exceeding the $80 \%-125 \%$ limit). Clinicians should continue to advise separating other medications from patiromer by at least 3 hours and keep abreast of future product-labeling changes. The FDA is now requiring Concordia Pharmaceuticals Inc (Oakville, ON, Canada), the manufacturer of SPS, to perform drug-interaction studies based on these results for patiromer. ${ }^{27}$ There are no drug-interaction data currently available for ZS9. Given the specificity for the potassium ion and inorganic structure of this molecule, it is less likely that it will possess significant interactions. Nonetheless, it is expected that drug-interaction studies will follow suit with those of patiromer and SPS.

\section{Clinical trial results Patiromer}

Following two Phase II and one Phase III clinical trials, the FDA approved patiromer (Veltassa, Relypsa) for the treatment of hyperkalemia on October 21, 2015. ${ }^{19,28,29}$ Table 2 summarizes the study designs, patient populations, and major findings of the clinical trials for patiromer. ${ }^{19,28-30}$

The PEARL-HF trial was designed to assess the safety, efficacy, and tolerability of patiromer in 105 heart failure patients with either CKD (estimated glomerular filtration rate $[\mathrm{eGFR}]<60 \mathrm{~mL} / \mathrm{min}$ ) or a history of hyperkalemia (Table 2). ${ }^{29}$ A majority of patients had mild heart failure, and spironolactone was initiated in all patients. The subset of CKD patients had a mean potassium reduction of -0.14 $\mathrm{mEq} / \mathrm{L}$ in the patiromer group from baseline to week 4 compared to an increase of $0.38 \mathrm{mEq} / \mathrm{L}$ in the placebo group (mean difference $-0.52 \mathrm{mEq} / \mathrm{L}, P=0.031$ ), which was similar to the overall population. Spironolactone was able to be increased from $25 \mathrm{mg} /$ day to $50 \mathrm{mg} /$ day in $91 \%$ of patiromer patients compared to $74 \%$ of placebo patients $(P=0.019)$. Adverse cardiac effects in these heart failure patients were rare and unlikely related to patiromer: two patients had worsening of coronary artery disease, one patient developed atrial fibrillation, and one patient experienced a myocardial infarction. Hypomagnesemia occurred in $23.2 \%$ (13 of 56) of patients receiving patiromer compared to $2.0 \%$ (one of $49)$ of patients on placebo $(P<0.05)$. This patient population experienced flatulence $(7.1 \%$; four of 56$)$ and vomiting (3.6\%; two of 56), which were not reported in patients with CKD in the other studies.

Patients with severe GI disorders, kidney transplants, or receiving dialysis were excluded. ${ }^{29}$ The mean baseline values for potassium $(4.69 \mathrm{mEq} / \mathrm{L})$ and eGFR $(81 \mathrm{~mL} / \mathrm{min})$ were within normal limits, although $50 \%$ of patients had eGFR $<60$ $\mathrm{mL} / \mathrm{min}$. Therefore, the study population represented a clinically stable cohort with mild heart failure, mild-to-moderate CKD, and normal baseline potassium. One patiromer-dosing regimen was studied, and no titration was allowed. This did not necessarily mimic clinical practice, as patiromer dosing would be adjusted to maintain normal potassium while titrating such an renin-angiotensin-aldosterone system inhibitor (RAASI) as spironolactone. The trial duration of 28 days was short for what appears to be a chronic indication. This trial provided valuable information for an at-risk population that was not exclusively evaluated in the other studies using a placebo control.

The AMETHYST-DN study was designed to determine the safety, efficacy, and optimal dosing of patiromer in 306 outpatients with hyperkalemia and CKD (Table 2). ${ }^{28}$ After a 4-week run-in phase where RAASI therapy was initiated and/ or titrated, patiromer doses were adjusted to maintain target potassium of 4-5 mEq/L. All patients continued to receive treatment with RAASIs throughout the study duration. The least-squares mean reduction in potassium from baseline to week 4 ranged from $-0.35 \mathrm{mEq} / \mathrm{L}$ to $-0.97 \mathrm{mEq} / \mathrm{L}$ in a dosedependent manner. In a 44-week maintenance phase $(n=262)$, the proportion of patients with normal potassium $(3.8-5$ $\mathrm{mEq} / \mathrm{L})$ at each visit through week 52 was $83.1 \%-92.7 \%$ in the mild-hyperkalemia group and $77.4 \%-95.1 \%$ in the moderate-hyperkalemia group.

Common adverse effects experienced by patients in this study were constipation (6.3\% [19 of 304]) and diarrhea $(5.6 \%$ [17 of 304]). ${ }^{28}$ Additionally, hypokalemia occurred in 5.6\% (17 of 304) and hypomagnesemia in 8.6\% (26 of 304) of patients on patiromer. Worsening CKD (9.2\% [28 of 304]) and hypertension (7.9\% [24 of 304]) were observed, but progression of these diseases is inherent to their nature. Discontinuation of therapy due to an adverse event over the 52 -week study period occurred in 28 patients on patiromer $(9.2 \%)$.

While this study provided valuable long-term data on the use of patiromer, the multiple-treatment groups (six total) without statistical adjustment for multiple comparisons are concerning. ${ }^{28}$ However, the purpose of this Phase II trial was not to test efficacy but rather test dose ranges to be utilized in the following Phase III trial. The open-label design introduced the risk of selection and/or measurement bias. In addition, no comparative placebo group was included. Patients were male (63.2\%), Caucasian (100\%), and mostly from Europe. Generalizability to patients in the US, female, and of other ethnicities is unknown from these data. Patients with New York Heart Association (NYHA) class III or IV were excluded and 2\% (six of 306) had an eGFR 
$<15 \mathrm{~mL} / \mathrm{min} / 1.73 \mathrm{~m}^{2}$, thereby preventing interpretation in these high-risk populations.

The OPAL-HK Phase III trial evaluated the efficacy and safety of patiromer in 243 CKD patients with hyperkalemia (Table 2). ${ }^{19}$ At week 8 of the randomized withdrawal phase, the recurrence of hyperkalemia (potassium $>5.0 \mathrm{mEq} / \mathrm{L}$ ) was observed in $43 \%$ (95\% CI 30\%-56\%) of patients on patiromer compared to $91 \%$ (95\% CI 83\%-99\%) on placebo $(P<0.001)$. An exploratory analysis demonstrated that $94 \%$ of patients on patiromer were able to continue RAASI therapy by the end of the randomized phase compared to $44 \%$ of placebo patients ( $P$-value not provided). At least one adverse effect was observed in $47 \%$ (114 of 243) of patients on patiromer during the initial phase. During the randomized phase, the occurrence of an adverse event was similar in patiromer patients ( $47 \%$ [ 26 of 55]) and placebo patients (50\% [26 of 52]). The most common adverse effects of patiromer during the initial treatment phase were constipation ( $11 \%$ [ 26 of 243]), diarrhea ( $3 \%$ [eight of 243]), nausea (3\% [eight of 243], and hypomagnesemia (3\% [eight of 243]). Hypokalemia occurred in 3\% of patients during the initial treatment period and follow-up.

This diverse population included patients with CKD, heart failure, and type 2 diabetes mellitus. ${ }^{19}$ However, those with NYHA class IV heart failure, prior kidney transplant, in need of a transplant, or severe GI disorders were excluded. All but four patients were Caucasian. This limits generalizability to patients with higher disease severity and of other ethnicities. In addition, patients were counseled to restrict their dietary intake of potassium to less than $3 \mathrm{~g}$ /day. While important from an efficacy study-design perspective, this may impact the pragmatism of the results, since not all patients are able to control and monitor their daily intake of potassium in practice. The initial treatment phase was observational and not placebo-controlled. This study may not have adequately depicted the usefulness of patiromer for chronic hyperkalemia, given the 12-week duration. Nonetheless, the OPAL-HK study demonstrated clear efficacy for patiromer for managing mild-to-moderate hyperkalemia in patients with CKD, heart failure, and receiving an RAASI.

Data from patients with heart failure in the OPAL-HK trial were analyzed to determine the effects of patiromer in this patient population. ${ }^{31}$ The end points of interest were the same as those in the main study. By week 4 of the initial phase (open-label patiromer, $n=102$ patients with heart failure), a mean reduction in potassium from baseline of $-1.06 \pm 0.05 \mathrm{mEq} / \mathrm{L}(95 \% \mathrm{CI}-1.16$ to $-0.95 \mathrm{mEq} / \mathrm{L}, P<0.001)$ was observed. In the randomized withdrawal phase including 49 heart failure patients, there was a between-group difference in median reduction in potassium of $-0.64 \mathrm{mEq} / \mathrm{L}$ ( $95 \% \mathrm{CI}-0.99$ to $-0.29 \mathrm{mEq} / \mathrm{L}, \mathrm{P}<0.001)$ by week 4 . In an exploratory analysis, $100 \%$ of heart failure patients on patiromer were able to continue RAASI therapy by the end of the randomized phase compared to $55 \%$ of placebo patients ( $P$-value not provided). Adverse effects experienced by heart failure patients on patiromer occurred at rates similar to those of the general study population from OPAL-HK. Of note, hypokalemia occurred in 3.9\% (five of 129) and hypomagnesemia in $3.1 \%$ (four of 129) of patients receiving patiromer. There were no strict diagnostic criteria for heart failure in this substudy. A majority of patients (65\%) had NYHA class II disease. This subgroup analysis revealed similar results as the primary trial, indicating that heart failure patients are likely to derive the same benefit from patiromer as other patient groups.

Based on the consistent results of these four studies, patiromer appears to play a significant role as maintenance treatment for hyperkalemia and in initiating, maintaining, and titrating RAASI therapy in patients with CKD and/or heart failure. ${ }^{19,28,29,31}$ However, acute hyperkalemia still presents a major treatment gap. A smaller trial aimed to determine the time-dependent effects of patiromer in acute hyperkalemia (Table 2).$^{30}$ Mean potassium reduction was $-0.75 \mathrm{mEq} / \mathrm{L}$ (95\% $\mathrm{CI}-0.89$ to $-0.61 \mathrm{mEq} / \mathrm{L})$ by 48 hours $(P<0.001)$. An exploratory analysis demonstrated that $20 \%$ of patients achieved potassium of $5.5 \mathrm{mEq} / \mathrm{L}$ or lower after 7 hours. Additionally, normal potassium concentration $(3.5-5.0 \mathrm{mEq} / \mathrm{L})$ was achieved by $20 \%$ of patients after 31 hours. The most common adverse effects experienced were constipation and hypotension, with each occurring in $8 \%$ (two of 25 ) of patiromer patients. Although the sample size was small, this 2-day study demonstrated the potential effects of patiromer as an acute treatment in patients with moderate hyperkalemia and CKD. Based on these results, it is not advisable to use patiromer in the acute setting, as a majority of patients did not achieve potassium $<5.5 \mathrm{mEq} / \mathrm{L}$ within 7 hours. This is congruent with current product-label recommendations..$^{20}$ Since the studied dose was $8.4 \mathrm{~g}$ twice daily for four doses, additional studies are necessary to determine if a more extensive reduction in potassium concentration is possible with more aggressive dosing.

\section{Sodium zirconium cyclosilicate}

The FDA is currently reviewing a new drug application for ZS9 in the treatment of hyperkalemia following one Phase II and two Phase III clinical trials. ${ }^{18,25,32}$ Table 3 summarizes the study designs, patient populations, and major findings of the clinical trials for ZS9. ${ }^{18,25,32}$ 
Table 3 Summary of sodium zirconium cyclosilicate (ZS9) clinical studies for the treatment of hyperkalemia

\begin{tabular}{|c|c|c|}
\hline Study design & Patient population & $\begin{array}{l}\text { Primary end } \\
\text { point(s) }\end{array}$ \\
\hline $\begin{array}{l}\text { Phase II, prospective, } \\
\text { randomized, } \\
\text { double-blind, } \\
\text { placebo-controlled, } \\
\text { dose-escalating } \\
\text { clinical trial }^{33}\end{array}$ & $\begin{array}{l}\text { Patients with stable } \\
\text { stage } 3 \mathrm{CKD}(\mathrm{eGFR} \\
\left.30-59 \mathrm{~mL} / \mathrm{min} / 1.73 \mathrm{~m}^{2}\right) \\
\text { and mild-to-moderate } \\
\text { hyperkalemia } \\
(5-6 \mathrm{mEq} / \mathrm{L})(\mathrm{n}=90)\end{array}$ & $\begin{array}{l}\text { Rate of potassium } \\
\text { concentration decline } \\
\text { in the first } 48 \text { hours }\end{array}$ \\
\hline
\end{tabular}

$\begin{aligned} & \text { Study treatment } \\ & \text { and duration }\end{aligned}$
ZS9 $0.3 \mathrm{~g}, 3 \mathrm{~g}$, or $10 \mathrm{~g}$
PO three times daily
with meals or placebo
for 48 hours (six doses)

Major findings

Mean \pm SD

potassium-concentration reduction from baseline of $-0.1 \mathrm{I} \pm 0.46 \mathrm{mEq} / \mathrm{L}$ at I hour with ZS9 $10 \mathrm{~g}$ compared to an increase of $0.12 \pm 0.36 \mathrm{mEq} / \mathrm{L}$ with placebo $(P=0.04)$; reduction of $-0.92 \pm 0.52 \mathrm{mEq} / \mathrm{L}$ with ZS9 $10 \mathrm{~g}$ at 38 hours compared to $-0.26 \pm 0.4 \mathrm{mEq} / \mathrm{L}$ with placebo $(P<0.00 \mathrm{I})$

Phase III, prospective, randomized, double-blind, placebo-controlled, two-stage, dose-ranging clinical trial ${ }^{18}$

\section{Initial phase: ambulatory outpatients with hyperkalemia (5-6.5 mEq/L) $(n=754)$}

(2)

\begin{abstract}
Initial phase: rate of change in mean potassium concentration compared to placebo over 48 hours
\end{abstract}

Maintenance phase:
mean potassium
concentration
compared to placebo
over 12 days

Change in potassium concentration over 48 hours
HARMONIZE:

Phase III, prospective, randomized, double-blind, placebo-controlled clinical trial ${ }^{25}$

\section{Open-label phase: ambulatory outpatients with hyperkalemia $(\geq 5.1 \mathrm{mEq} / \mathrm{L})(\mathrm{n}=258)$ \\ Maintenance phase: mbulatory outpatients $(3.5-4.9 \mathrm{mEq} / \mathrm{L})$ at hour 48 of the initial phase $(n=543)$}

\begin{abstract}
Initial phase: ZS9 I.25, $2.5 \mathrm{~g}, 5 \mathrm{~g}$, or $10 \mathrm{~g}$ PO three times daily with meals or placebo for 48 hours
\end{abstract}

Maintenance phase: ZS9 dose from initial phase given once daily before breakfast or switched to placebo for days 3-I4

Open-label phase: ZS9 I0 g PO three times daily with meals for 2 days
Initial phase: mean

potassium-concentration reductions (per hour) of $-0.16 \%$ for 2.5 g group, $-0.21 \%$ for $5 \mathrm{~g}$ group, $-0.30 \%$ for $10 \mathrm{~g}$ group, and $-0.09 \%$ for placebo ( $P<0.00$ I for each comparison) Maintenance phase: mean potassium concentration increases (per hour) of $0.14 \%$ for $10 \mathrm{~g}$ group vs $1.04 \%$ for placebo $(P<0.00 I)$; increases of $0.09 \%$ for 5 g group vs $0.47 \%$ for placebo $(P=0.008)$ Open-label phase: by 48 hours, the mean rate of potassium-concentration reduction (per hour) was $-0.3 \%$ ( $95 \% \mathrm{Cl}-0.4 \%$ to $-0.3 \%$ ); the mean absolute reduction was I.I $\mathrm{mEq} / \mathrm{L}(95 \% \mathrm{Cl}-\mathrm{I} . \mathrm{I}$ to $-1.0 \mathrm{mEq} / \mathrm{L}, P<0.00 \mathrm{I})$

Randomized phase: mean potassium of $4.8 \mathrm{mEq} / \mathrm{L}$ (95\% Cl 4.6-4.9mEq/L) for 5 g group, $4.5 \mathrm{mEq} / \mathrm{L}(95 \%$ Cl 4.4-4.6 mEq/L) for $10 \mathrm{~g}$ group, and $4.4 \mathrm{mEq} / \mathrm{L}(95 \% \mathrm{Cl}$ $4.3-4.5 \mathrm{mEq} / \mathrm{L})$ for $15 \mathrm{~g}$ group compared to $5.1 \mathrm{mEq} / \mathrm{L}(95 \%$ Cl 5-5.2 mEq/L) for placebo ( $P<0.00$ I for each comparison)

Abbreviations: $\mathrm{Cl}$, confidence interval; CKD, chronic kidney disease; eGFR, estimated glomerular filtration rate; PO, per os (by mouth); SD, standard deviation.

A Phase II clinical trial was designed to determine the safety, efficacy, and optimal dosing of ZS9 in 90 patients with hyperkalemia and stage $3 \mathrm{CKD}$ (Table 3$).{ }^{32}$ A potassium reduction greater than $1.0 \mathrm{mEq} / \mathrm{L}$ occurred in $41.7 \%$ of patients on the $10 \mathrm{~g}$ dose compared to $3.4 \%$ on placebo by hour 38 of the study. The $3 \mathrm{~g}$ and $10 \mathrm{~g}$ groups experienced a greater rate of potassium concentration reduction over 48 hours compared to placebo $(P=0.048$ and $P<0.0001$, respectively). In 66 patients receiving RAASI therapy, the $10 \mathrm{~g}$ dose produced a mean reduction of $-0.12 \pm 0.50 \mathrm{mEq} / \mathrm{L}$ by 1 hour compared to a mean increase of $0.19 \pm 0.31 \mathrm{mEq} / \mathrm{L}$ with placebo $(P<0.03)$. The most common adverse effects were nausea, vomiting, and urinary tract infection, with each occurring in 5\% (three of 60) of ZS9 patients. A dosedependent increase in serum bicarbonate was observed in this study. In the ZS9 group, the mean bicarbonate concentration 
increased from $27.4 \mathrm{mEq} / \mathrm{L}$ at baseline to $30.1 \mathrm{mEq} / \mathrm{L}$ on day $2(P=0.05)$. Patients with $\mathrm{CKD}$ also experienced a mean reduction in blood urea nitrogen from baseline ranged from -3 to $-5 \mathrm{mg} / \mathrm{dL}$ on days $2-7(P<0.05$ vs placebo). These effects are likely the result of ammonium-ion trapping and excretion with ZS9. This study included a mix of males $(58 \%)$ and females $(42 \%)$, all from the US. However, the patient population was focused to stage 3 CKD (eGFR 30-59 mL/ $\min / 1.73 \mathrm{~m}^{2}$ ), few patients had potassium $>5.5 \mathrm{mEq} / \mathrm{L}$, a majority of patients were Caucasian (98\%), the sample size was small, and the study had a short duration. These limitations require further $\mathrm{ZS} 9$ investigation in a larger number of more diverse patients for an extended period of time.

A Phase III clinical trial of 754 outpatients aimed to determine the efficacy, safety, and optimal dosing of ZS9 for hyperkalemia (Table 3 ). ${ }^{18}$ The population included $61 \%$ with CKD, $40 \%$ with heart failure, and $67 \%$ on RAASI therapy. In the initial phase, the $10 \mathrm{~g}$ dose produced a mean reduction in potassium from baseline of $-0.11 \mathrm{mEq} / \mathrm{L}(95 \% \mathrm{CI}$ -0.17 to $-0.05 \mathrm{mEq} / \mathrm{L}$ ) by 1 hour compared to an increase of $0.01 \mathrm{mEq} / \mathrm{L}$ with placebo $(95 \% \mathrm{CI}-0.05$ to $0.07 \mathrm{mEq} / \mathrm{L}$, $P=0.009)$. The absolute reduction in potassium at 48 hours was $-0.73 \mathrm{mEq} / \mathrm{L}(95 \% \mathrm{CI}-0.82$ to $-0.65 \mathrm{mEq} / \mathrm{L})$ for the $10 \mathrm{~g}$ group and $-0.25 \mathrm{mEq} / \mathrm{L}$ for the placebo group $(95 \% \mathrm{CI}$ -0.32 to $-0.19 \mathrm{mEq} / \mathrm{L}, P<0.001$ for the comparison). Normal potassium concentration $(3.5-4.9 \mathrm{mEq} / \mathrm{L})$ was achieved in the $5 \mathrm{~g}$ and $10 \mathrm{~g}$ groups, regardless of the history of CKD, heart failure, or RAASI utilization. However, the study was not adequately powered for subgroup analyses.

The occurrence of at least one adverse effect was similar between the ZS9 and placebo groups during the initial phase (12.9\% [77 of 596] vs $10.8 \%$ [17 of 158], respectively) and the randomized phase $(25.1 \%$ [ 82 of 327$]$ vs $24.5 \%$ [53 of 216], respectively). ${ }^{18}$ Diarrhea was the most common adverse effect, occurring in $1.8 \%$ of patients on ZS9 and $2.5 \%$ of placebo patients during the initial phase. As in the previous study, a dose-dependent increase in serum bicarbonate was observed with ZS9, but values remained within normal limits. Prolongation of the corrected QT (QTc) interval was noted with ZS9. Mean increases ranged from 0.03 to 10.3 milliseconds. An increase of 71 milliseconds occurred in one patient, but they were receiving concomitant treatment with ciprofloxacin. Once ciprofloxacin was discontinued, the QTc interval returned to the baseline value. Of note, there was no difference in the rate of clinically significant arrhythmias between the ZS9 and placebo groups. The severity of CKD and heart failure were not specified, which limits the generalizability of these results. Since outpatients were included and $85 \%$ were Caucasian, the results should be cautiously applied (if at all) to hospitalized patients or those of other ethnicities. Another limitation was that baseline serum potassium concentrations were not the same between placebo and treatment groups $(P<0.05)$, with higher concentrations in the treatment groups. The double-blind, placebo-controlled initial phase was unique to this study and provides excellent efficacy data. Rates of potassium decline in the initial phase demonstrate that ZS9 is likely to have an acute benefit for patients with mild-to-moderate hyperkalemia, but patients with severe hyperkalemia were not studied.

The HARMONIZE Phase III trial evaluated the efficacy and safety of ZS9 for 28 days in outpatients with hyperkalemia (Table 3). ${ }^{25}$ Of the 258 patients, $66 \%$ had CKD, 36\% had heart failure, and $70 \%$ were on RAASI therapy. In the open-label phase, ZS9 $10 \mathrm{~g}$ three times daily produced a mean reduction in potassium from baseline of $-0.2 \mathrm{mEq} / \mathrm{L}(95 \%$ $\mathrm{CI}-0.3$ to $-0.2 \mathrm{mEq} / \mathrm{L})$ by 1 hour and $-0.4 \mathrm{mEq} / \mathrm{L}(95 \% \mathrm{CI}$ -0.5 to $-0.4 \mathrm{mEq} / \mathrm{L})$ by 2 hours $(P<0.001$ for both comparisons to placebo). Patients on RAASI therapy achieved a mean potassium reduction of $-1.02 \mathrm{mEq} / \mathrm{L}$ (95\% CI -1.17 to -0.9 $\mathrm{mEq} / \mathrm{L})$ by hour 48 , which was similar to the overall study population $(-1.1 \mathrm{mEq} / \mathrm{L} ; 95 \% \mathrm{CI}-1.1$ to $-1.0 \mathrm{mEq} / \mathrm{L})$. Normal potassium concentration $(3.5-5 \mathrm{mEq} / \mathrm{L})$ was achieved by $84 \%(95 \%$ CI $79 \%-88 \%)$ of patients within 24 hours and 98\% (95\% CI 96\%-99\%) within 48 hours. At least one adverse event was observed in 7.8\% (20 of 258) of patients on ZS9 during the initial phase. During the randomized phase, $42.1 \%$ (64 of 152) of ZS9 patients experienced an adverse effect compared to $31.8 \%$ (27 of 85 ) of placebo patients. Hypokalemia occurred in 7.2\% (11 of 152) of patients receiving ZS9, but hypomagnesemia was not observed. As in the previous study, ambulatory outpatients were included and the majority were Caucasian. Many patients had CKD and heart failure, but disease severity was mild to moderate (eGFR $46.3 \pm 30.5 \mathrm{~mL} / \mathrm{min} / 1.73 \mathrm{~m}^{2}$ ). The initial phase had an open-label design, introducing selection and measurement biases. While a study duration of 4 weeks was sufficient to demonstrate ZS9 efficacy for acutely lowering potassium, longer trial durations are needed to define its role in chronic therapy.

Data from patients with heart failure in the HARMONIZE study were analyzed to determine the effects of ZS9 in this population. ${ }^{33}$ The end points of interest were the same as those in the main study. In the open-label phase ( $n=94)$, ZS9 reduced potassium to $4.4 \mathrm{mEq} / \mathrm{L}(95 \% \mathrm{CI} 4.3-4.5 \mathrm{mEq} / \mathrm{L})$ from a baseline of $5.6 \mathrm{mEq} / \mathrm{L}(95 \%$ CI $5.5-5.7 \mathrm{mEq} / \mathrm{L})$ in 48 hours. During the randomized phase $(n=87)$, mean potassium 
concentrations of $4.7 \mathrm{mEq} / \mathrm{L}(95 \%$ CI $4.5-4.9 \mathrm{mEq} / \mathrm{L}), 4.5$ $\mathrm{mEq} / \mathrm{L}(95 \% \mathrm{CI} 4.3-4.6 \mathrm{mEq} / \mathrm{L})$, and $4.4 \mathrm{mEq} / \mathrm{L}(95 \%$ CI $4.2-4.5 \mathrm{mEq} / \mathrm{L}$ ) were achieved in the $5 \mathrm{~g}, 10 \mathrm{~g}$, and 15 g groups, respectively, compared to $5.2 \mathrm{mEq} / \mathrm{L}(95 \% \mathrm{CI}$ $5-5.4 \mathrm{mEq} / \mathrm{L})$ with placebo ( $P<0.001$ for each comparison). Patients continuing RAASI therapy experienced similar efficacy results, but no specific data were provided. As for adverse effects, edema was observed in $13.1 \%$ (eight of 61 ) of heart failure patients on ZS9 compared to $3.8 \%$ (one of 26) of those on placebo. Additionally, worsening hypertension occurred in $6.6 \%$ (four of 61 ) of ZS9 patients compared to $3.8 \%$ (one of 26 ) of placebo patients. No strict diagnostic criteria for heart failure were utilized to determine eligibility in this substudy. However, this likely had minimal impact on this subgroup analysis, because the efficacy of ZS9 demonstrated in patients with heart failure appears to be similar to that of the main study sample.

In both of the Phase III clinical trials, the most pronounced effects of ZS9 were observed in patients with the highest baseline potassium concentration. ${ }^{18,25}$ Therefore, the results of these studies were combined to analyze the effects of ZS9 in a larger cohort of patients $(n=45)$ with severe hyperkalemia (potassium $\geq 6.0 \mathrm{mEq} / \mathrm{L}$ ) ${ }^{34} \mathrm{~A}$ single $10 \mathrm{~g}$ dose produced a mean reduction in potassium from baseline of $-0.4 \mathrm{mEq} / \mathrm{L}(95 \% \mathrm{CI}-0.5$ to $-0.2 \mathrm{mEq} / \mathrm{L})$ by 1 hour, -0.6 $\mathrm{mEq} / \mathrm{L}(95 \% \mathrm{CI}-0.8$ to $-0.4 \mathrm{mEq} / \mathrm{L})$ by 2 hours, and -0.7 $\mathrm{mEq} / \mathrm{L}(95 \% \mathrm{CI}-0.9$ to $-0.6 \mathrm{mEq} / \mathrm{L})$ by 4 hours $(P<0.001$ for each comparison to baseline). The median time to potassium lower than $6.0 \mathrm{mEq} / \mathrm{L}$ was 1.07 hours, and $80 \%$ of patients achieved this by 4 hours. In addition, the median time to potassium concentration of $5.5 \mathrm{mEq} / \mathrm{L}$ or lower was 4 hours. This subgroup analysis provides valuable information, albeit in only 45 patients. ZS9 was effective at reducing severe hyperkalemia to a safe concentration within 4 hours for a majority of patients. Other studies are needed to clarify the optimal dose and should include an inpatient population, but these data are promising for ZS9 as an alternative to SPS in acute, severe hyperkalemia.

\section{SPS}

Table 4 summarizes the designs, patient populations, and major findings of the clinical studies for SPS. ${ }^{35-37}$ To date, there have been two randomized clinical trials of SPS. ${ }^{36,37}$ An observational study is included in this evidence review for historical context. ${ }^{35}$

A prospective observational study performed in 1961 evaluated the safety and efficacy of SPS in 32 hyperkalemic patients with either acute or CKD (Table 4). ${ }^{35}$ Patients were placed on a potassium-restricted diet and received SPS orally $(n=24)$ or rectally $(n=8)$ if the patient was unable to take fluids by mouth. No control group was used. By 24 hours, there was a mean serum potassium reduction of $-1.0 \mathrm{mEq} / \mathrm{L}$ in the oral administration group and $-0.8 \mathrm{mEq} / \mathrm{L}$ in the rectal administration group. Treatment with SPS was ineffective for two patients whose potassium concentrations increased by 24 hours to values of $6.8 \mathrm{mEq} / \mathrm{L}$ and $8.3 \mathrm{mEq} / \mathrm{L}$. As for safety, patients experienced nausea, vomiting, and constipation, but specific data regarding the number of occurrences for each were not provided. Two of the patients in the oral administration group were given SPS three times per week for a few months to display its long-term effect. These patients had follow-up potassium concentrations of $4.2 \mathrm{mEq} / \mathrm{L}$ and $6.3 \mathrm{mEq} / \mathrm{L}$. These data do not support the use of SPS for chronic, long-term treatment of hyperkalemia, due to the unspecified follow-up time frame utilized and the continuation of clinically relevant hyperkalemia in one of the patients. All of the patients in the study were on a potassium-restricted diet, three patients received glucose and insulin along with SPS, and five patients received sodium bicarbonate concomitantly. These confounding factors limit the merit of the study. Additionally, only nine CKD patients were included, which makes it difficult to generalize these results to that patient population. Despite the reduction in potassium demonstrated, mean baseline values and statistical significance testing were not provided, which in addition to the small sample size further limits the clinical relevance of these data.

A randomized, single-blind clinical trial assessed the safety and efficacy of SPS in 97 CKD patients with potassium concentration greater than $5.2 \mathrm{mEq} / \mathrm{L}$ (Table 4). ${ }^{36}$ In patients receiving SPS $(n=47)$, the mean potassium concentration decreased from a baseline of $5.8 \pm 0.6 \mathrm{mEq} / \mathrm{L}$ to $4.3 \pm 0.53$ $\mathrm{mEq} / \mathrm{L}$ by day 3 . The most common adverse effects observed in the SPS group were nausea (42.6\% [20 of 47]), anorexia (34\% [16 of 47]), and worsening edema (8.5\% [four of 47]). Additionally, patients receiving SPS experienced an increase in diastolic blood pressure to $82.2 \pm 11.7 \mathrm{mmHg}$ from a baseline of $76.67 \pm 9.3 \mathrm{mmHg}(P=0.004)$. Although no significant electrolyte variations were demonstrated, the occurrence of these effects may have been limited, because the study lasted only 3 days, serum magnesium-concentration monitoring was not performed, and the dose of SPS used ( $5 \mathrm{~g}$ three times daily) was lower than the standard dose (15-30 g per dose, up to four times daily). A serum creatinine concentration greater than $1.5 \mathrm{mg} / \mathrm{dL}$ was an inclusion criterion and all patients had stage $1-4 \mathrm{CKD}$, but the exact number of patients with each stage was not noted. Furthermore, patients 
Table 4 Summary of SPS clinical studies for the treatment of hyperkalemia

\begin{tabular}{|c|c|c|c|c|}
\hline Study design & Patient population & Primary end point(s) & $\begin{array}{l}\text { Study treatment and } \\
\text { duration }\end{array}$ & Major findings \\
\hline $\begin{array}{l}\text { Prospective } \\
\text { observational } \\
\text { study }^{36}\end{array}$ & $\begin{array}{l}\text { Patients with either acute } \\
\text { or CKD and hyperkalemia } \\
(\mathrm{n}=32)\end{array}$ & $\begin{array}{l}\text { Mean change in potassium } \\
\text { concentration over } 24 \\
\text { hours }\end{array}$ & $\begin{array}{l}\text { SPS } 20-60 \mathrm{~g} / \text { day PO in four } \\
\text { divided doses or } 10-40 \mathrm{~g} \\
\text { rectally and repeated in } \\
4-12 \text { hours if necessary } \\
\text { (dosage varied with the } \\
\text { degree of hyperkalemia and } \\
\text { the course of renal failure) }\end{array}$ & $\begin{array}{l}\text { Mean potassium concentration } \\
\text { reduction of }-1.0 \mathrm{mEq} / \mathrm{L} \text { in the } \mathrm{PO} \\
\text { group and }-0.8 \mathrm{mEq} / \mathrm{L} \text { in the rectal } \\
\text { administration group }\end{array}$ \\
\hline $\begin{array}{l}\text { Prospective, } \\
\text { randomized, } \\
\text { single-blind } \\
\text { clinical trial }{ }^{37}\end{array}$ & $\begin{array}{l}\text { Patients with CKD }(\mathrm{SCr}>\mathrm{I} .5 \\
\mathrm{mg} / \mathrm{dL}) \text { and hyperkalemia } \\
(>5.2 \mathrm{mEq} / \mathrm{L})(\mathrm{n}=97)\end{array}$ & $\begin{array}{l}\text { Mean change in potassium } \\
\text { concentration over } 3 \text { days }\end{array}$ & $\begin{array}{l}\text { SPS } 5 \mathrm{~g} \text { PO TID or CPS } 5 \mathrm{~g} \\
\text { PO TID for } 3 \text { days }\end{array}$ & $\begin{array}{l}\text { Mean } \pm \text { SD baseline potassium } \\
5.8 \pm 0.6 \mathrm{mEq} / \mathrm{L} \text { in SPS group; } \\
\text { potassium concentration decreased } \\
\text { to } 4.3 \pm 0.53 \mathrm{mEq} / \mathrm{L} \text { by day } 3\end{array}$ \\
\hline $\begin{array}{l}\text { Prospective, } \\
\text { randomized, } \\
\text { double-blind, } \\
\text { placebo-controlled } \\
\text { clinical trial }^{38}\end{array}$ & $\begin{array}{l}\text { Outpatients with CKD } \\
\left.\text { (eGFR }<40 \mathrm{~mL} / \mathrm{min} / \mathrm{l} .73 \mathrm{~m}^{2}\right) \\
\text { and mild hyperkalemia } \\
(5-5.9 \mathrm{mEq} / \mathrm{L})(\mathrm{n}=33)\end{array}$ & $\begin{array}{l}\text { Mean change in potassium } \\
\text { concentration from } \\
\text { baseline to day } 7\end{array}$ & $\begin{array}{l}\text { SPS } 30 \text { g PO once daily or } \\
\text { placebo for } 7 \text { days }\end{array}$ & $\begin{array}{l}\text { Mean potassium concentration } \\
\text { reduction of }-\mathrm{I} .25 \pm 0.56 \mathrm{mEq} / \mathrm{L} \\
\text { in the } \mathrm{SPS} \text { group compared to } \\
-0.2 \mathrm{I} \pm 0.29 \mathrm{mEq} / \mathrm{L} \text { in the placebo } \\
\text { group (mean difference }-\mathrm{I} .04 \\
\mathrm{mEq} / \mathrm{L}, 95 \% \mathrm{Cl}-\mathrm{I} .37 \text { to }-0.7 \mathrm{I} \\
\mathrm{mEq} / \mathrm{L} ; \mathrm{P}<0.00 \mathrm{I} \text { ) }\end{array}$ \\
\hline
\end{tabular}

Abbreviations: $\mathrm{Cl}$, confidence interval; CKD, chronic kidney disease; CPS, calcium polystyrene sulfonate; eGFR, estimated glomerular filtration rate; PO, per os (by mouth); $\mathrm{SCr}$, serum creatinine; SD, standard deviation; SPS, sodium polystyrene sulfonate; TID, ter in die (three times daily).

on RAASI therapy or a $\beta$-blocker were excluded from the study. Therefore, it is difficult to generalize these results to patients with advanced stages of CKD or who receive common, essential medications.

A recent randomized, placebo-controlled clinical trial aimed to determine the safety and efficacy of SPS in 33 CKD patients with mild hyperkalemia (Table 4). ${ }^{37}$ Patients receiving SPS $(n=16)$ had a mean baseline potassium concentration of $5.2 \mathrm{mEq} / \mathrm{L}$. By day 7 , there was a mean potassium reduction of $-1.25 \pm 0.56 \mathrm{mEq} / \mathrm{L}$ from baseline in the SPS group compared to $-0.21 \pm 0.29 \mathrm{mEq} / \mathrm{L}$ in the placebo group (mean difference $-1.04 \mathrm{mEq} / \mathrm{L}, 95 \% \mathrm{CI}-1.37$ to $-0.71 \mathrm{mEq} / \mathrm{L} ; P<0.001)$. Normal potassium concentration $(3.5-4.9 \mathrm{mEq} / \mathrm{L})$ was achieved by $73 \%$ of SPS patients and $38 \%$ of placebo patients $(P=0.07)$. While this result was not statistically significant, it may reflect a type II error due to small sample size. The most common adverse events experienced were nausea, vomiting, and constipation, which occurred in $25 \%$ (four of 16 ), $12.5 \%$ (two of 16 ), and $37.5 \%$ (six of 16 ) of patients on SPS, respectively. One patient in the SPS group withdrew from the study on day 3 due to severe vomiting, and two patients receiving SPS required a laxative-dose increase. Hypomagnesemia occurred in $31.3 \%$ (five of 16 ) and hypocalcemia in $18.8 \%$ (three of 16) of SPS patients. Although rare GI adverse events, such as colonic necrosis, were not observed, the capacity for detection was limited by the small sample size. Patients were excluded if their dose of an RAASI had been adjusted within
60 days prior to initiation of the study. Since RAASI therapy is essential for patients with CKD and/or heart failure, it is ideal for hyperkalemia treatment options to be able to maintain normokalemia during titration of these medications, which this study was unable to demonstrate. Although specific diet restrictions were not implemented, $25 \%$ (four of 16) of patients on SPS were fasting (last meal $>8$ hours) prior to potassium concentration measurement on day 7 compared to $5.9 \%$ (one of 17) of placebo patients, which may confound the results. This study aimed to assess the efficacy of SPS in chronic hyperkalemia patients, but the study duration was only 7 days. Due to the small sample size, mild degree of hyperkalemia at baseline, and short duration, an evidence gap remains for long-term efficacy of SPS.

\section{Discussion}

Clinical trials have demonstrated that patiromer and ZS9 are safe and effective for the treatment of hyperkalemia in high-risk patient populations. Patiromer was approved by the FDA for this indication in October 2015 and is now available for use. The resubmitted new drug application for ZS9 was accepted for review by the FDA in October 2016 after concerns about preapproval manufacturing inspections were addressed. The FDA approved SPS for the treatment of hyperkalemia in 1958. Although past studies were observational in nature, two recent clinical trials demonstrated its efficacy in the chronic setting. 


\section{Acute treatment}

Acute hyperkalemia remains a significant concern, due to the potential for life-threatening arrhythmias. Previously, efficacy data for acute hyperkalemia were elusive and placebo-controlled interventions unlikely, given ethical considerations. The use of SPS in acute hyperkalemia is complicated by a variable onset of action (2-6 hours), a variable duration of action (6-24 hours), and a lack of robust efficacy data, although it was previously the only FDA-approved medication for potassium removal. ${ }^{10,15,16}$ Despite the potassium reduction demonstrated in the 1961 SPS study, the clinical relevance is limited because mean baseline values and statistical significance testing were not provided, the sample size was small, and confounding factors were present. Interpretation of the data from three ZS9 clinical trials indicates a significant potential role for ZS9 in the management of acute hyperkalemia. The onset of effect is 1 hour, with a dosedependent, predictable potassium-lowering response. Data from patients with mild-to-moderate hyperkalemia indicate a predictable decline in potassium concentration of -0.11 to $-0.2 \mathrm{mEq} / \mathrm{L}$ by hour 1 and -0.73 to $-1.1 \mathrm{mEq} / \mathrm{L}$ by hour 48. ${ }^{18,25,32}$ None of the ZS9 clinical trials studied patients with acute hyperkalemia, so further research in this population is necessary. Patiromer was studied for the treatment of acute hyperkalemia. ${ }^{30}$ However, the onset of effect was 7 hours, and the mean potassium concentration reduction achieved was $0.21 \mathrm{mEq} / \mathrm{L}$. These results demonstrate that it is not advisable to use patiromer in the acute setting, which is consistent with current product-label recommendations. ${ }^{20}$ Based on the published data, ZS9 appears to be the preferred agent for the treatment of acute hyperkalemia when compared to patiromer and SPS. However, a randomized controlled trial directly comparing these medications would be necessary to validate this recommendation.

\section{Chronic treatment}

Chronic hyperkalemia is common in patients with diabetes mellitus, CKD, heart failure, and those utilizing RAASI therapy. ${ }^{6}$ Current treatment strategies of loop diuretics or intermittent SPS are insufficient, due to variable potassiumlowering effects and toxicity potential. Despite the efficacy demonstrated by SPS in two clinical trials, many questions regarding its use in this population remain unanswered, due to small sample sizes, mild degree of hyperkalemia at baseline, and short study durations. Compared to ZS9, patiromer appears to play a more significant role for the maintenance of normokalemia. Patiromer clinical trials showed a dose-dependent potassium reduction with efficacy through follow-up periods of 12 weeks and 52 weeks. ${ }^{19,28}$ Limitations to these results are that the 52-week period was open-label and not placebo-controlled and that twice-daily patiromer dosing was utilized, whereas the FDA-approved dosing is once daily. Postmarketing studies are warranted to confirm the optimal dosing strategy. Nonetheless, normal serum potassium concentration was maintained in $77.4 \%-95.1 \%$ of patients over the study period. ${ }^{28}$ Although ZS9 was effective at lowering potassium and has potential for the treatment of chronic hyperkalemia, short trial durations of 2-28 days do not allow for extrapolation to this use. Critical long-term follow-up data for ZS9 will be forthcoming as the results of the HARMONIZE extension trial (NCT02107092) and another 12-month trial (NCT02163499) are reported. Overall, patiromer appears to be the preferred agent for the treatment of chronic hyperkalemia when compared to ZS9 and SPS. However, these medications would need to be compared in a randomized controlled trial in order to validate this recommendation.

\section{Special populations}

Hyperkalemia is a serious medical condition that is associated with increased mortality, especially in patients with severe hyperkalemia. ${ }^{1-3}$ The most pronounced effects from ZS9 were observed in patients with the highest baseline potassium concentration. ${ }^{18,25}$ In a subgroup of patients with potassium concentrations of $6.1-7.2 \mathrm{mEq} / \mathrm{L}, \mathrm{ZS} 9$ dosed at $10 \mathrm{~g}$ produced a mean reduction of $0.4 \mathrm{mEq} / \mathrm{L}$ within 1 hour, and $52 \%$ of patients reached potassium of $5.5 \mathrm{mEq} / \mathrm{L}$ or lower within 4 hours. ${ }^{34}$ Despite these results, none of the trials for ZS9 were conducted in hospitalized patients or specifically designed to assess treatment in patients with acute, severe hyperkalemia. Therefore, these extrapolated findings require further study in the inpatient setting before strong recommendations for the use of these agents can be made for acute, severe hyperkalemia. Hyperkalemia often limits the use of RAASI therapy in patients with compelling indications for these drugs (CKD and/or heart failure patients). ${ }^{6}$ Although two clinical trials have assessed the efficacy of SPS in CKD patients, one excluded patients on RAASI therapy ${ }^{36}$ and the other excluded patients who received an RAASI-dose adjustment. ${ }^{37}$ Therefore, practitioners should cautiously monitor potassium concentration during RAASI continuation or dose titration in CKD patients on SPS. However, efficacy data for patiromer and ZS9 were similar for subgroups of patients with CKD, heart failure, and those receiving RAASI therapy. Additionally, both patiromer and ZS9 allowed for the initiation, titration, and maintenance of RAASI therapy in these 
populations that derive significant benefit. Despite this, additional high-risk patient populations, such as dialysis patients, renal transplant recipients, patients with GI disorders, and postsurgical patients, were excluded from the clinical trials. Therefore, further research should address these populations. Until then, clinicians should use patiromer and ZS9 cautiously in these patients or avoid their use.

\section{Safety/drug interactions}

Patiromer and ZS9 were generally well tolerated, with the most common adverse events being nausea, constipation, and diarrhea. None of these effects were severe, and they occurred less frequently than has been historically observed with SPS. The use of SPS has also been associated with rare GI effects, such as mucosal damage and intestinal necrosis. ${ }^{12-14}$ While serious adverse effects are rare, nausea, vomiting, and diarrhea occur frequently and limit the long-term tolerability of the medication. Patiromer- and ZS9-treated patients did not experience any severe GI effects. However, with only 660 courses of patiromer treatment and 1,393 courses of ZS9 treatment evaluable from clinical trials, Phase IV postmarketing surveillance will be critical to identify rare adverse events. Compared to patiromer, GI adverse events were experienced less often with ZS9, and rates were comparable to those demonstrated in placebo groups. ZS9 has an inorganic lattice structure that does not swell in gastric juices, which may be the reason for this observed difference.

As for electrolyte variations, hypomagnesemia was not reported in any ZS9 clinical trial, and hypokalemia occurred less frequently. The high specificity of ZS9 for the potassium ion could explain these observed differences in electrolyte abnormalities. Since patiromer can also bind magnesium, hypomagnesemia was observed in every patiromer clinical trial. Therefore, patients' magnesium concentrations should be monitored frequently, and patients should be educated on the potential symptoms of hypomagnesemia, such as muscle weakness/cramping, nystagmus, and numbness. Hypokalemia, which most of the studies defined as a potassium concentration lower than $3.5 \mathrm{mEq} / \mathrm{L}$, was also observed in patients receiving patiromer. Caution should be used when lowering the potassium concentration in patients with heart failure and/or CKD because values lower than $4.0 \mathrm{mEq} / \mathrm{L}$ may be associated with increased mortality. ${ }^{38,39}$ In addition to these electrolyte variations, SPS can cause hypocalcemia and hypernatremia, with the latter likely related to the medication's sodium content. A $15 \mathrm{~g}$ dose of SPS contains 1,500 $\mathrm{mg}$ of sodium, whereas ZS9 contains approximately 1,000 $\mathrm{mg}$ of sodium in a $10 \mathrm{~g}$ dose and patiromer has no sodium content. The higher sodium content of SPS is troublesome for this often sodium-restricted patient population. ${ }^{11}$

Patients on ZS9 experienced unique adverse events, such as edema, urinary tract infections, and QTc-interval prolongation. However, prolongation of the QTc interval is a physiologic effect of acutely lowering serum potassium concentration. The increase in QTc interval (0.03-10 milliseconds) was not clinically relevant, and rates of arrhythmia were no different between ZS9 and placebo groups. ${ }^{18}$ Interestingly, a slight increase in serum bicarbonate concentration and a small decrease in blood urea nitrogen content were observed during the use of ZS9. This effect occurs presumably through ammonium-ion trapping and excretion. This may have potential benefit for patients with CKD, who often have concomitant metabolic acidosis, but that remains hypothetical. Overall, patiromer and ZS9 appear to be safe medications, with most patients tolerating therapy well.

Patient adherence is a concern for all three of these agents. Both ZS9 and patiromer products are suspensions that require multiple cycles of mixing to be performed manually by the patient to ensure the complete dose is administered. Initially, ZS9 is dosed three times daily, which is cumbersome. Patiromer binds with other medications in the GI tract, which necessitates a 3-hour separation for administering other medications..$^{20}$ It is important to note that the drug-interaction studies included healthy volunteers and did not take into account the multiple medications this patient population is often receiving. Further clinical research is necessary to define the optimal timing of administration. Proper patient education on the mixing, administration, and timing of these medications will be critical to ensure adherence and effectiveness.

\section{Conclusion}

Patiromer and ZS9 are significant advancements for the treatment of hyperkalemia. These drugs have enhanced specificity for the potassium ion, a more predictable reduction in serum potassium concentration, and an improved safety profile compared to SPS. Patiromer and ZS9 are different in terms of their pharmacologic properties, adherence potential, interactions with concomitant medications, and safety profiles. Based on the currently available evidence, patiromer seems to be the preferred agent for the treatment of chronic hyperkalemia, whereas ZS9 may have a role in the treatment of acute hyperkalemia. The evidence base for SPS is more limited than these new agents. Use of SPS may continue, due to clinical familiarity and lower cost. Comparative trials among patiromer, ZS9, and SPS would provide essential evidence and should be considered in the future. 


\section{Acknowledgment}

Mario V Beccari was a PharmD student at the University at Buffalo School of Pharmacy and Pharmaceutical Sciences during the completion of this manuscript.

\section{Disclosure}

The authors report no actual or potential conflicts of interest in this work.

\section{References}

1. Evans KJ, Greenberg A. Hyperkalemia: a review. J Intensive Care Med. 2005;20(5):272-290.

2. Weiner ID, Wingo CS. Hyperkalemia: a potential silent killer. JAm Soc Nephrol. 1998;9(8):1535-1543.

3. Jain N, Kotla S, Little BB, et al. Predictors of hyperkalemia and death in patients with cardiac and renal disease. Am J Cardiol. 2012;109(10): 1510-1513.

4. Palmer BF. Regulation of potassium homeostasis. Clin J Am Soc Nephrol. 2015;10(6):1050-1060.

5. Salem CB, Badreddine A, Fathallah N, Slim R, Hmouda H. Druginduced hyperkalemia. Drug Saf. 2014;37(9):677-692.

6. Palmer BF. Managing hyperkalemia caused by inhibitors of the renin-angiotensin-aldosterone system. $N$ Engl J Med. 2004;351(6): 585-592.

7. Perazella MA. Drug-induced hyperkalemia: old culprits and new offenders. Am J Med. 2000;109(4):307-314.

8. [No authors listed]. KDIGO 2012 clinical practice guideline for the evaluation and management of chronic kidney disease. Kidney Int Suppl. 2013;3(1):1-150.

9. Yancy CW, Jessup M, Bozkurt B, et al. 2013 ACCF/AHA guideline for the management of heart failure: a report of the American College of Cardiology Foundation/American Heart Association Task Force on Practice Guidelines. Circulation. 2013;128(16):e240-e327.

10. Emmett M, Hootkins RE, Fine KD, Santa Ana CA, Porter JL, Fordtran JS. Effect of three laxatives and a cation exchange resin on fecal sodium and potassium excretion. Gastroenterology. 1995;108(3):752-760.

11. Kayexalate (sodium polystyrene sulfonate, USP) [package insert]. Bridgewater, NJ: Sanofi-Aventis; 2009.

12. Cheng ES, Stringer KM, Pegg SP. Colonic necrosis and perforation following oral sodium polystyrene sulfonate (Resonium A/Kayexalate) in a burn patient. Burns. 2002;28(2):189-190.

13. Gerstman BB, Kirkman R, Platt R. Intestinal necrosis associated with postoperative orally administered sodium polystyrene sulfonate in sorbitol. Am J Kidney Dis. 1992;20(2):159-161.

14. Harel Z, Harel S, Shah PS, Wald R, Perl J, Bell CM. Gastrointestinal adverse events with sodium polystyrene sulfonate (Kayexalate) use: a systematic review. Am J Med. 2013;126(3):264.e9-e24.

15. Sterns RH, Rojas M, Bernstein P, Chennupati S. Ion-exchange resins for the treatment of hyperkalemia: are they safe and effective? $\mathrm{J} \mathrm{Am}$ Soc Nephrol. 2010;21(5):733-735.

16. Gruy-Kapral C, Emmett M, Santa Ana CA, Porter JL, Fordtran JS, Fine KD. Effect of single dose resin-cathartic therapy on serum potassium concentration in patients with end-stage renal disease. J Am Soc Nephrol. 1998;9(10):1924-1930.

17. Watson M, Abbott KC, Yuan CM. Damned if you do, damned if you don't: potassium binding resins in hyperkalemia. Clin J Am Soc Nephrol. 2010;5(10):1723-1726.

18. Packham DK, Rasmussen HS, Lavin PT, et al. Sodium zirconium cyclosilicate in hyperkalemia. N Engl J Med. 2015;372(3):222-231.

19. Weir MR, Bakris GL, Bushinsky DA, et al. Patiromer in patients with kidney disease and hyperkalemia receiving RAAS inhibitors. $N$ Engl J Med. 2015;372(3):211-221.
20. Veltassa (Patiromer) [package insert]. Redwood City, CA: Relypsa; 2015.

21. Montaperto AG, Gandhi MA, Gashlin LZ, Symoniak MR. Patiromer: a clinical review. Curr Med Res Opin. 2016;32(1):155-164.

22. Epstein M, Palmer B, Mayo M, et al. Mechanism of action of patiromer for oral suspension: increases fecal $\mathrm{K}^{+}$excretion in healthy volunteers independent of race. 2015. Available from: http://www.posters2view. eu/wcn2015/view.php?nu=3287. Accessed March 3, 2017.

23. Stavros F, Yang A, Leon A, Nuttall M, Rasmussen HS. Characterization of structure and function of ZS-9, a K+ selective ion trap. PLoS One. 2014;9(12):e114686.

24. Packham DK, Rasmussen HS, Lavin PT, et al. Sodium zirconium cyclosilicate in hyperkalemia. N Engl J Med. 2015;372(3):222-231.

25. Kosiborod M, Rasmussen HS, Lavin P, et al. Effect of sodium zirconium cyclosilicate on potassium lowering for 28 days among outpatients with hyperkalemia: the HARMONIZE randomized clinical trial. JAMA. 2014;312(21):2223-2233.

26. Center for Drug Evaluation and Research. Clinical pharmacology and biopharmaceutics review(s) - application number: 205739Orig1s000 2015. Available from: http://www.accessdata.fda.gov/drugsatfda_docs/ nda/2015/205739Orig1s000ClinPharmR.pdf. Accessed February 1, 2016.

27. US Food and Drug Administration. FDA drug safety communication: FDA requires drug interaction studies with potassium-lowering drug Kayexalate (sodium polystyrene sulfonate). 2015. Available from: http://www.fda.gov/ Drugs/DrugSafety/ucm468035.htm. Accessed February 1, 2016.

28. Bakris GL, Pitt B, Weir MR, et al. Effect of patiromer on serum potassium level in patients with hyperkalemia and diabetic kidney disease: the AMETHYST-DN randomized clinical trial. JAMA. 2015;314(2):151-161.

29. Pitt B, Anker SD, Bushinsky DA, Kitzman DW, Zannad F, Huang IZ. Evaluation of the efficacy and safety of RLY5016, a polymeric potassium binder, in a double-blind, placebo-controlled study in patients with chronic heart failure (the PEARL-HF) trial. Eur Heart J. 2011;32(7):820-828.

30. Bushinsky DA, Williams GH, Pitt B, et al. Patiromer induces rapid and sustained potassium lowering in patients with chronic kidney disease and hyperkalemia. Kidney Int. 2015;88(6):1427-1433.

31. Pitt B, Bakris GL, Bushinsky DA, et al. Effect of patiromer on reducing serum potassium and preventing recurrent hyperkalaemia in patients with heart failure and chronic kidney disease on RAAS inhibitors. Eur $J$ Heart Fail. 2015;17(10):1057-1065.

32. Ash SR, Singh B, Lavin PT, Stavros F, Rasmussen HS. A phase 2 study on the treatment of hyperkalemia in patients with chronic kidney disease suggests that the selective potassium trap, ZS-9, is safe and efficient. Kidney Int. 2015;88(2):404-411.

33. Anker SD, Kosiborod M, Zannad F, et al. Maintenance of serum potassium with sodium zirconium cyclosilicate (ZS-9) in heart failure patients: results from a phase 3 randomized, double-blind, placebocontrolled trial. Eur J Heart Fail. 2015;17(10):1050-1056.

34. Kosiborod M, Peacock WF, Packham DK. Sodium zirconium cyclosilicate for urgent therapy of severe hyperkalemia. $N \mathrm{Engl} \mathrm{J} \mathrm{Med.}$ 2015;372(16):1577-1578.

35. Scherr L, Ogden DA, Mead AW, Spritz N, Rubin AL. Management of hyperkalemia with a cation-exchange resin. $N$ Engl J Med. 1961;264(3):115-119.

36. Nasir K, Ahmad A. Treatment of hyperkalemia in patients with chronic kidney disease: a comparison of calcium polystyrene sulphonate and sodium polystyrene sulphonate. JAyub Med Coll Abbottabad. 2014;26(4):455-458.

37. Lepage L, Dufour AC, Doiron J, et al. Randomized clinical trial of sodium polystyrene sulfonate for the treatment of mild hyperkalemia in CKD. Clin J Am Soc Nephrol. 2015;10(12):2136-2142.

38. Kjeldsen K. Hypokalemia and sudden cardiac death. Exp Clin Cardiol. 2010;15(4):e96-e99.

39. Bowling CB, Pitt B, Ahmed MI, et al. Hypokalemia and outcomes in patients with chronic heart failure and chronic kidney disease: findings from propensity-matched studies. Circ Heart Fail. 2010;3(2):253-260. 


\section{Publish your work in this journal}

Core Evidence is an international, peer-reviewed open-access journal evaluating the evidence underlying the potential place in therapy of drugs throughout their development lifecycle from preclinical to post launch. The focus of each review is to evaluate the case for a new drug or class in outcome terms in specific indications and patient groups.

Submit your manuscript here: https://www.dovepress.com/core-evidence-journal
The manuscript management system is completely online and includes a very quick and fair peer-review system, which is all easy to use. Visit http://www.dovepress.com/testimonials.php to read real quotes from published authors. 